\title{
Probiotic modulation of the gut bacterial community of juvenile Litopenaeus vannamei challenged with Vibrio parahaemolyticus CAIM 170
}

\author{
Irasema E. Luis-Villaseñor ${ }^{1,2}$, Domenico Voltolina ${ }^{3}$, Bruno Gomez-Gil ${ }^{4}$, Felipe Ascencio ${ }^{2}$ \\ Ángel I. Campa-Córdova ${ }^{2}$, Juan M. Audelo-Naranjo ${ }^{1} \&$ Olga O. Zamudio-Armenta ${ }^{1}$ \\ ${ }^{1}$ Facultad de Ciencias del Mar, Universidad Autónoma de Sinaloa (UAS) \\ Mazatlán, Sinaloa, CP 82000, México \\ ${ }^{2}$ Centro de Investigaciones Biológicas del Noroeste (CIBNOR), La Paz, B.C.S., CP 23096, México \\ ${ }^{3}$ Centro de Investigaciones Biológicas del Noroeste, Laboratorio UAS-CIBNOR \\ Mazatlán, Sinaloa, CP 82000, México \\ ${ }^{4}$ Centro de Investigación en Alimentación y Desarrollo (CIAD), Mazatlán Unit for Aquaculture \\ Mazatlán, Sinaloa, CP 82000, México \\ Corresponding author: Ángel I. Campa-Córdova (angcamp04@cibnor.mx)
}

\begin{abstract}
The protective effects of two probiotic mixtures was studied using the fingerprints of the bacterial community of Litopenaeus vannamei juveniles exposed to probiotics and challenged with Vibrio parahaemolyticus CAIM 170. Fingerprints were constructed using 16S rRNA gene and the PCR-SSCP (Single strand conformation polymorphism) technique, and the probiotics used were an experimental Bacillus mixture (Bacillus tequilensis YC5-2 + B. endophyticus C2-2 and YC3-B) and the commercial probiotic Alibio. The DNA for PCR-SSCP analyses was extracted directly from the guts of shrimps treated for 20 days with the probiotics and injected with $2.5 \times 10^{5} \mathrm{CFU} \mathrm{g}^{-1}$ of $\mathrm{V}$. parahaemolyticus one week after suspension of the probiotic treatment. Untreated shrimps served as positive (injected with $V$. parahaemolyticus) and negative (not injected) controls Analysis of the bacterial community carried out after inoculation and 12 and $48 \mathrm{~h}$ later confirmed that $V$. parahaemolyticus was present in shrimps of the positive control, but not in the negative control or treated with the probiotic mixtures. A significant difference in the diversity of the bacterial community was observed between times after infection. The band patterns in $0-12 \mathrm{~h}$ were clustered into a different group from that determined after $48 \mathrm{~h}$, and suggested that during bacterial infection the guts of whiteleg shrimp were dominated by gamma proteobacteria represented by Vibrio sp. and Photobacterium sp. Our results indicate that the experimental and the commercial mixtures are suitable to modulate the bacterial community of L. vannamei and could be used as a probiotic to control vibriosis in juvenile shrimp.
\end{abstract}

Keywords: Litopenaeus vannamei, Bacillus mix, Vibrio parahaemolyticus, bacterial community, aquaculture.

\section{Modulación por probióticos de la comunidad bacteriana intestinal de juveniles de Litopenaeus vannamei infectados con Vibrio parahaemolyticus CAIM 170}

RESUMEN. Se estudiaron los perfiles de bandeo de la comunidad bacteriana de juveniles de Litopenaeus vannamei tratados con dos probióticos y expuesto a la bacteria patógena Vibrio parahaemolyticus CAIM 170. Los perfiles de bandeo se construyeron usando el gen 16S rRNA y la técnica PCR-SSCP (Polimorfismo conformacional de cadena sencilla) y los probióticos fueron una mezcla experimental de Bacillus (Bacillus tequilensis YC5-2 y B. endophyticus C2-2 y C3-B) y el probiótico comercial Alibio. El ADN para el análisis PCR-SSCP se obtuvo de los intestinos de camarones tratados durante 20 días con los probióticos, inyectados con $2,5 \times 10^{5}$ UFC $\mathrm{g}^{-1}$ de $V$. parahaemolyticus una semana después de la suspensión del tratamiento con probióticos. Camarones no tratados con probióticos sirvieron como control positivo (inyectados con $V$. parahaemolyticus) y negativo (no inyectados). El análisis de la comunidad bacteriana durante el reto confirmó la presencia del patógeno inyectado en el control positivo y su ausencia en el negativo y en los organismos tratados con probióticos. Durante las 48 h del período experimental se observó una diferencia significativa en la diversidad de la comunidad bacteriana.

Corresponding editor: Sandra Bravo 
Los patrones de bandas se agruparon en un grupo a las 0-12 h y en uno diferente después de $48 \mathrm{~h}$ y sugirieron que los intestinos de camarón blanco fueron dominados por gamma proteobacteria representados por Vibrio sp. y Photobacterium sp. durante la infección bacteriana. Estos resultados indican que las dos mezclas pueden modular la comunidad bacteriana y pueden ser usadas como probióticos para controlar la vibriosis en camarones juveniles.

Palabras clave: Litopenaeus vannamei, mezcla de Bacillus, Vibrio parahaemolyticus, comunidad bacteriana, acuicultura.

\section{INTRODUCTION}

The bacterial genus Vibrio is common and widely distributed in the natural marine environment and in the microbiota of farmed shrimp ponds (Gopal et al., 2005), where some of its species may become opportunistic pathogens and sources of major diseases when the natural defense mechanisms of cultured shrimp are suppressed (Lightner, 2005).

Under the common name of vibriosis, these diseases may cause considerable economic losses, and are considered among the most serious limiting factors for the success of marine aquaculture (Lightner, 2005; Chatterjee \& Haldar, 2012). Among the etiological agents, Vibrio harveyi, V. vulnificus, V. parahaemolyticus, $V$. campbelli, V. alginolyticus and $V$. penaeicida have been associated with cultured shrimp diseases (Ishimaru et al., 1995; Sahul-Hameed et al., 1996; Jayasree et al., 2006), and among these $V$. harveyi and $V$. alginolyticus are thought to be the most common causes of disease during larval and postlarval development (Manefield et al., 2000; Abraham \& Palaniappan, 2004).

The addition of probiotic bacteria to culture systems has gained attention as a precautionary measure against pathogens. This addition aims to reduce or eliminate selected pathogenic species and to improve growth and survival of the cultured species through the modulation of the microbial communities of the culture environment (Balcázar et al., 2006; Martínez-Cruz et al., 2012), because bacteria may affect growth and survival of aquatic organisms and are a major element in their well being, since they play distinct roles in the host organism, which are associated with nutrition, immune responses and disease resistance (Austin, 2006; Chaiyapechara et al., 2011; Tuyub-Tzuc et al., 2014).

Culture-independent techniques for population fingerprinting, such as denaturing gradient gel electrophoresis (DGGE) and single strand conformation polymorphism (SSCP), are effective tools for a more complete and rapid assessment of microbial diversity, especially of complex ecosystems such as intestinal microbiota (Muyzer \& Smalla, 1998; Dohrmann \& Tebbe, 2004; Hassan, 2012).
Previous experiments showed that a Bacillus mixture which improved survival and development of Litopenaeus vannamei larvae caused also an increase in diversity and evenness of the bacterial community of the larval gut, thus increasing resistance to $V$. parahaemolyticus infection (Luis-Villaseñor et al., $2011,2013)$. However, there is no information on the effect of this or other probiotics on the structure of the bacterial community of the intestinal tract of juvenile or adult shrimp challenged with pathogenic bacteria. This study aimed to evaluate the changes induced by the same Bacillus mixture on the gut bacterial community of juvenile Litopenaeus vannamei (Pacific whiteleg shrimp) infected with $V$. parahaemolyticus.

\section{MATERIALS AND METHODS}

\section{Probiotic strains}

Cultures of the bacteria Bacillus tequilensis YC5-2, B. endophyticus $\mathrm{C} 2-2$ and $B$. endophyticus YC3-B were grown at $37^{\circ} \mathrm{C}$ for $24 \mathrm{~h}$ in $200 \mathrm{~mL}$ Erlenmeyer flasks with $100-\mathrm{mL}$ of TSB medium, and concentrated by centrifugation at $5000 \times \mathrm{g}$ for $10 \mathrm{~min}$. Each pellet was suspended in a sterile saline solution containing 3\% (w/v) $\mathrm{NaCl}$ (S-7653, Sigma, St. Louis, MO). The absorbance was adjusted to an optical density of 1 at $600 \mathrm{~nm}$ (approximately $1 \times 10^{9} \mathrm{CFU} \mathrm{mL}^{-1}$ ), and the resulting suspensions were added to the shrimp rearing system at a final concentration of $1 \times 10^{5} \mathrm{CFU} \mathrm{mL} \mathrm{mL}^{-1}$.

\section{Pathogenic bacterium}

Strain Vibrio parahaemolyticus CAIM 170, obtained from the Colección de Microorganismos de Importancia Acuicola (CIAD, Mazatlan, Mexico, www.ciad. $\mathrm{mx} / \mathrm{caim}$ ), grown in trypticase soy broth (TS\#236950, Difco, Franklin Lakes, NJ) with $3 \%$ (w/v) $\mathrm{NaCl}$, was centrifuged at $5000 \times \mathrm{g}$ for $10 \mathrm{~min}$; the pellet was suspended in $3 \%(\mathrm{w} / \mathrm{v})$ sterile saline solution. The bacterial suspension was diluted with filtered sterile seawater to an optical density of 1.0 (approximate concentration: $1 \times 10^{9} \mathrm{CFU} \mathrm{mL}^{-1}$ ), and a 1:10 dilution of this suspension was used for the challenge experiment.

\section{Probiotic treatment and infection}

Juvenile shrimps (mean live weight $8 \pm 1 \mathrm{~g}$ ) were obtained from a commercial hatchery and acclimated 
for five days to laboratory conditions, which did not change throughout the experiment $(5-\mu \mathrm{m}$ filtered seawater, $29^{\circ} \mathrm{C}$ and salinity 36) in a common tank. After acclimation, 16 groups of 21 shrimps were placed in 80-L aquaria. Five aquaria (treatment A) were added

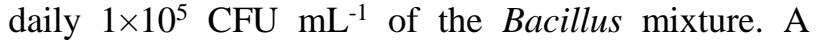
second group of five aquaria (treatment $\mathrm{B}$ ) received the dose used by local shrimp farmers $\left(1 \mathrm{~mL} \mathrm{~L}^{-1}\right.$, with

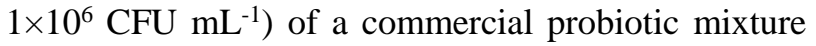
(Alibio2135 + AlibioAC + Alibio Bionutre) activated as recommended by the manufacturer (AliBio S.A. de C.V., Mexico City). The remaining six aquaria served as triplicate positive and negative (unchallenged) controls (treatments C and D, respectively).

Addition of probiotics was suspended after 20 days, and seven days later all shrimps of treatments A, B and $\mathrm{C}$ were injected into the fifth abdominal section with 20 $\mu \mathrm{L}$ of Vibrio suspension $\left(=1 \times 10^{8} \mathrm{CFU} \mathrm{mL}^{-1}\right)$, giving $2 \times 10^{6} \mathrm{CFU} /$ shrimp. Shrimps of treatment D were injected with a sterile saline solution.

Throughout the experiment all treatments were fed ad libitum a $35 \%$ protein commercial diet. Continuous aeration was maintained in all aquaria, which were maintained with $50 \%$ daily water exchanges.

\section{Sample collection and DNA extraction}

One shrimp was randomly selected from each container immediately after Vibrio injection (time 0) (5 shrimps for each probiotic treatment and 3 shrimps for positive and negative controls), and sampling was repeated after 12 and $48 \mathrm{~h}$, in the first case because this time coincided with the first case of mortality, while the last was observed $12 \mathrm{~h}$ later. Consequently, samples of live shrimp were taken at times $12 \mathrm{~h}$ (onset of mortality) and $48 \mathrm{~h}$, giving the surviving shrimp 24 to recover after the last observed death. Immediately after sampling, the body surface of each shrimp was washed with sterile seawater, disinfected with $70 \%$ ethanol, dissected with sterile instruments and the entire intestinal tract was removed, excised with sterile forceps and scissors, and preserved at $-80^{\circ} \mathrm{C}$ in individual screw-capped tubes with $1 \mathrm{~mL}$ absolute ethanol.

At the end of the experiment, the chromosomal DNA was extracted to assay for the diversity of the intestinal communities, using Wizard genomic DNA purification kits (Promega, Madison, WI) according to the manufacturer's instructions.

\section{Amplification of 16S rRNA}

The universal bacterial primers Com1 and Com2ph were used to amplify a $407 \mathrm{bp}$ fragment corresponding to positions 519 to 926 (E. coli positions; including variable regions 4 and 5 of the $16 \mathrm{~S}$ gene). The Com1 sequence was 5'-CAGCAGCCGCGGTAATAC and Com2ph was 3'-CCGTCAATTCCTTTGAGTTT (Schwieger \& Tebbe, 1998). Each PCR was performed in a total volume of $50 \mu \mathrm{L}$ in $0.2 \mathrm{~mL}$ micro tubes. The reaction mixtures were contained in $1 \times \mathrm{PCR}$ buffer with $1.5 \mathrm{mM} \mathrm{MgCl}_{2}, 0.5 \mu \mathrm{M}$ of each primer, $200 \mu \mathrm{M}$ of each $\mathrm{dNTP}$, and $2.5 \mathrm{U}$ Taq polymerase (GoTaq, Promega). The total amount of genomic DNA added to the PCR mixtures was $250 \mathrm{ng}$. Thermocycling (Peltier Thermal Cycler, Bio-Rad Laboratories, Hercules, CA) started with an initial denaturation for $3 \mathrm{~min}$ at $94^{\circ} \mathrm{C}$, followed by 30 cycles of $60 \mathrm{~s}$ at $94^{\circ} \mathrm{C}$, one cycle for of $60 \mathrm{~s}$ at $53^{\circ} \mathrm{C}$ and one of $90 \mathrm{~s}$ at $72^{\circ} \mathrm{C}$, ending with a final extension for $5 \mathrm{~min}$ at $72^{\circ} \mathrm{C}$. The presence of specific PCR products was confirmed on $1 \%(\mathrm{w} / \mathrm{v})$ agarose gel.

\section{Single-strand conformation polymorphism}

The single-strand removal method (Schwieger \& Tebbe, 1998) was used for profiling bacterial communities. All PCR products of each replicate were purified (PCR purification kit, Qiagen, Hilden, Germany) and diluted in Tris-HCl buffer to a final volume of $20 \mu \mathrm{L}$. Samples were digested for $45 \mathrm{~min}$ at $37^{\circ} \mathrm{C}$ with $1 \mu \mathrm{L}(5 \mathrm{U})$ of lambda-exonuclease solution (New England Biolabs, Ipswich, MA), with $3 \mu \mathrm{L}$ exonuclease buffer and $6 \mu \mathrm{L}$ milli-Q $\mathrm{H}_{2} \mathrm{O}$, for a total volume of $30 \mu \mathrm{L}$. Digestion was stopped with the first step of purification with spin columns (MiniElute Kit, Qiagen), and diluted in $10 \mu \mathrm{L}$ Tris- $\mathrm{HCl}$ buffer.

A $9 \mu \mathrm{L}$ denaturing loading buffer containing $95 \%$ formamide (v/v), $10 \mathrm{mM} \mathrm{NaOH} \mathrm{(w/v),} 0.25 \%$ bromophenol blue (w/v), and $0.25 \%$ xylene cyanole $(\mathrm{w} / \mathrm{v})$ was added before electrophoretic analysis. Samples were incubated at $95^{\circ} \mathrm{C}$ for $2 \mathrm{~min}$ and immediately cooled on ice. After $3 \mathrm{~min}$, samples were loaded onto polyacrylamide gels of $0.625 \%$ MDE (Cambrex, East Rutherford, NJ), and electrophoresis at $260 \mathrm{~V}$ at $20^{\circ} \mathrm{C}$ was carried out for $18 \mathrm{~h}$ (DCode Universal Mutation System, Bio-Rad Laboratories, Hercules, CA). After electrophoresis was completed, the gel was stained with $\mathrm{AgNO}_{3}$ (Benbouza et al., 2006) and scanned using Power Look III (Umax Systems, Willich, Germany).

\section{Analysis of SSCP profiles}

Gel analysis software (Gel Compar II, Applied Maths, Sint-Martens-Latem, Belgium) was used to calculate similarities between profiles of bacteria obtained from the different treatments and times of inoculation, after image normalization with bacteria markers $(B$. licheniformis, Rhizobium trifolii, Flavobacterium johnsoniae, and $R$. radiobacter). The calculation of the similarity matrix was based on Pearson's correlation 
coefficients. The clustering method was the unweighted pair group method with arithmetic averages (UPGMA).

\section{Elution of bands and DNA sequencing}

Bands of interest were cut from the silver-stained polyacrylamide SSCP gel with a sterile scalpel. The single-stranded DNA was eluted from the gel by the crush and soak procedure (Sambrook \& Russell, 2001), resuspended in $12 \mu \mathrm{L}$ Tris buffer (10 mMTris- $\mathrm{HCl}, \mathrm{pH}$ 8.0), and amplified via PCR using primers Com1 and Com2ph under the conditions previously described. The PCR-amplified products were sequenced by a commercial firm (Genewiz, South Plainfield, NJ).

The sequences were compared with sequences in the GenBank database. The BLAST search of the National Center for Biotechnology Information and the EzTaxon server database (www.eztaxon.org; Chun et al., 2007) were used to determine the closest relationships of the $16 \mathrm{~s}$ rRNA sequences.

\section{Statistical analysis}

To determine the similarity between treatments, the data of the metrics obtained from each sample were exported as a binary matrix (PAST software, palaeoelectronica.org). A PCA was performed from the correlation matrices generated from a binary matrix, which was expressed as a value of Pearson's similarity coefficient (Fromin et al., 2002). A PCA analysis was conducted with software Statistica 6.0 (StatSoft, Tulsa, $\mathrm{OK})$.

\section{RESULTS}

\section{Modulation of intestinal microbiota}

The dendograms showed a clear modulation of the intestinal microbiota from $12 \mathrm{~h}$ post-infection (onset of death) to $48 \mathrm{~h}$ (organisms recovered), divided into two clusters. One cluster $(48 \mathrm{~h})$ had a similarity value of $40.81 \%$ with respect to the second cluster, including times 0 and $12 \mathrm{~h}$, with a percentage of similarity between 49.64\%. Samples Start 1 and Start 2 (samples taken before probiotic treatment) were within the same cluster as time $48 \mathrm{~h}$ with $54 \%$ similarity, indicating a recovery of the initial microbiota similar to the bioassay (Fig. 1).

\section{Bacterial community of juvenile shrimp infected by Vibrio parahaemolyticus}

The results from the SSCP fingerprint showed that the taxonomic group Flavobacteria was dominant: $\alpha$ proteobacteria (mainly Rugeria lacuscaerulensis), $\gamma$ proteobacteria, fusobacteria and Cytophagaceae, represented by Wandonia haliotis Haldis.
$V$. parahaemolyticus and Vibrio sp. were present only in the positive control, Cytophaga fermentans was present only in organisms treated with Alibio while Photobacterium damselae subs. piscicida was present in all treatments but not in the positive control. The individual bands present in the Bacillus mix were identified as Candidatus bacilloplasma mollicute and Nautella italica (Table 1). Unidentified bands (Uncultured bacteria) were also present in the treatment of the Bacillus mix.

Maribius salinus and Donghicola eburneus $(\alpha-$ proteobacteria) were detected only in the Bacillus mix and the positive control groups (Table 1). Bacteria species unique to the negative control were Thioprofundum lithotrophica, Sebaldella termitidis, Elizabethkingia anophelis, Oceanicola sp., and Thioclava pacifica. Thalassobium sp. was detected in both control groups.

\section{PCA Analysis}

Principal Component Analysis (PCA) showed that two of the components explained $91 \%$ of the total variance in the data (CP1 and CP2: 64.8 and 26.2\%, respectively) (Fig. 2), and that their factor loadings were considered significant at values greater than 0.70 . No significant differences were observed between the banding profiles at time $0 \mathrm{~h}$ and $12 \mathrm{~h}$, but their trends are separated clearly from that determined after $48 \mathrm{~h}$. These results coincide with the indications of the similarity dendrogram.

\section{DISCUSSION}

Manipulation of microbiota with probiotics may be a convenient practice to control or inhibit pathogenic bacteria in aquaculture, as well as to improve growth performance and digestive enzymes activities, and enhance immune responses against pathogens or physical stress (Balcázar et al., 2006; Pérez et al., 2010; Zokaeifar et al., 2012).

The Bacillus mix used in this work showed several effects which may be useful for $L$. vannamei culture: after a $V$. parahaemolyticus challenge which caused $>90 \%$ mortality in the control group, juvenile shrimps treated with this mix had significant higher survival, different total hemocyte concentrations and a higher diversity and evenness of their bacterial gut community than those treated with the commercial product Alibio, and demonstrated efficient probiotic protection (LuisVillaseñor et al., 2013). However, the underlying mechanisms for this protection remained unclear.

In this work we showed how the effect of $V$. parahaemolyticus CAIM 170 on the bacterial community of juvenile shrimp may be at least partially avoided in shrimps treated with the Bacillus mix even 


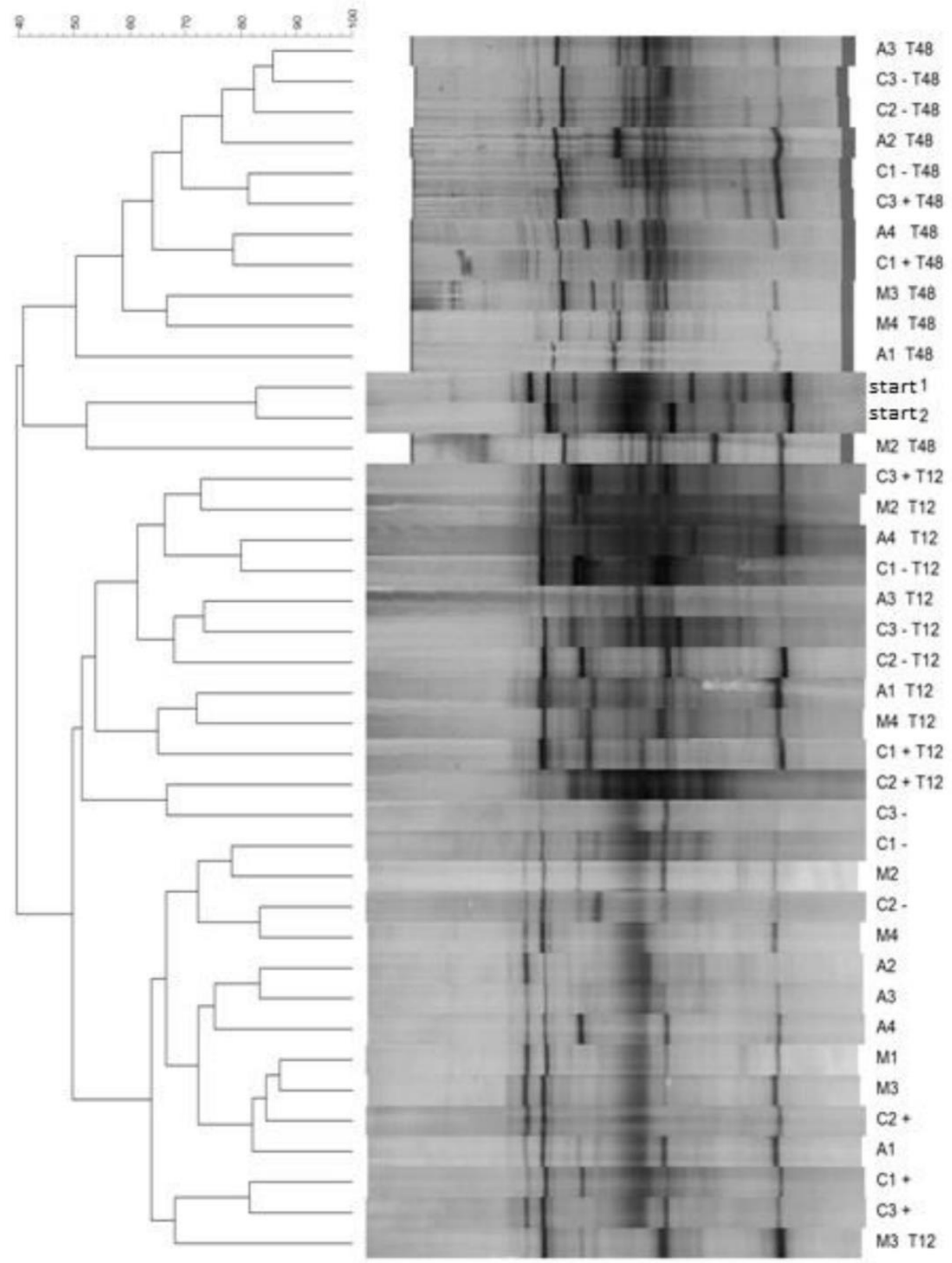

Figure 1. Acrylamide gel-generated via SSCP dendrogram illustrating the relationship (percent similarity) between bacterial communities in gut of shrimp at time $0 \mathrm{~h}, 12 \mathrm{~h}$ and $48 \mathrm{~h}$ : M1-M5 (Bacillus mix), A1-A5 (commercial probiotic), C1(-)-C3(-): (without probiotics and injected with saline solution) $\mathrm{C} 1(+)-\mathrm{C} 3(+)$ : (without probiotics and injected with pathogenic bacteria). Start 1 and 2: initial profiles, before probiotic treatment. The 40-100 scale of the dendrogram shows percent of similarity of the clusters. The dendrogram was calculated with UPGMA and the Dice coefficient.

after one week after suspension of the treatment. Although the SSCP distribution profiles displayed little variation of the number of bands (OTU) at each sampling period, the greatest variation observed was their increase $12 \mathrm{~h}$ after infection in all treatments with Vibrio.

The PCA of $0 \mathrm{~h}$ and $12 \mathrm{~h}$ indicated no evidence of clustering of individual probiotics groups and no statistically significant deviation from the baseline
SSCP profile. However, the PCA conducted on the 48 $\mathrm{h}$ gut samples showed the probiotic groups clustered separately from those at the beginning and those at 12 $\mathrm{h}$ post-infection. This indicated that the gut microbial population ecology of the animals at $48 \mathrm{~h}$ was significantly different from that at $0 \mathrm{~h}$ and $12 \mathrm{~h}$ after infection, and the separation more evident was that between probiotic-treated and $V$. parahaemolyticusinfected shrimps. 
Table 1. Closest relative, as determined by Blast search, with similarity (SIM, in \%) to the major OTUs from the 16S rRNA V4 and V5 SSCP gels.

\begin{tabular}{|c|c|c|c|}
\hline OTU & SIM (\%) & Closest relative & Phylogenetic group \\
\hline \multicolumn{4}{|c|}{ Bacillus mix } \\
\hline \multicolumn{4}{|c|}{ h 0} \\
\hline M1b & 96 & Nautella italica & $\alpha$-proteobacteria \\
\hline M1d & 90 & Candidatus bacilloplasma mollicute & \\
\hline M1c & 90 & Wandonia haliotis Haldis & Flavobateria \\
\hline M2a & 95 & Maribius salinus & $\alpha$-proteobacteria \\
\hline $\mathrm{M} 2 \mathrm{~b}$ & 98 & Donghicola eburneus & $\alpha$-proteobacteria \\
\hline \multicolumn{4}{|c|}{ h 12} \\
\hline M2a & 84 & Uncultured bacterium clone & \\
\hline M3a & 97 & Flavobacteriaceae bacterium & \\
\hline M3b & 97 & Flavobacteriaceae bacterium & \\
\hline M3c & 97 & Flavobacteriaceae bacterium & \\
\hline M3d & 97 & $\begin{array}{l}\text { Photobacterium damselae subs. piscicida } \\
48\end{array}$ & $\gamma$-proteobacteria \\
\hline M2a & 94 & Thalassobius gelatinovorus & $\alpha$-proteobacteria \\
\hline $\mathrm{M} 2 \mathrm{c}$ & 93 & Planktotalea frisia & $\alpha$-proteobacteria \\
\hline M2d & 98 & Ruegeria lacuscaerulensis & $\alpha$-proteobacteria \\
\hline $\mathrm{M} 2 \mathrm{~h}$ & 99 & Unidentified alpha proteobacterium & \\
\hline $\mathrm{M} 2 \mathrm{i}$ & 99 & Uncultured bacterium clone & \\
\hline \multicolumn{4}{|c|}{ Alibio } \\
\hline \multicolumn{4}{|c|}{ h 0} \\
\hline A1a & 90 & Wandonia haliotis Haldis & Flavobacteria \\
\hline A1c & 90 & Cytophaga fermentans & Cytophagaceae \\
\hline A1d & 90 & Sebaldella termitidis & \\
\hline $\mathrm{A} 4 \mathrm{a}$ & 90 & Wandonia haliotis Haldis & Flavobacteria \\
\hline $\mathrm{A} 4 \mathrm{~b}$ & 90 & Cytophaga fermentans & Cytophagaceae \\
\hline \multicolumn{4}{|c|}{ h 12} \\
\hline A1a & 97 & Flavobacteriaceae bacterium & \\
\hline A1b & 96 & Flavobacteriaceae bacterium & \\
\hline A1c & 89 & Uncultured bacterium clone & \\
\hline A1d & 90 & Cytophaga fermentans & Cytophagaceae \\
\hline A1e & 97 & Flavobacteriaceae bacterium & \\
\hline A1f & 98 & Photobacterium damselae sub sp. Piscicida & $\gamma$-proteobacteria \\
\hline A1g & 89 & Uncultured bacterium clone & \\
\hline Ali & 90 & Uncultured bacterium & \\
\hline $\mathrm{A} 1 \mathrm{j}$ & 87 & Vibrio furnissii & $\gamma$-proteobacteria \\
\hline A3a & 85 & Desulfovibrionaceae bacterium & \\
\hline A3b & 93 & Wandonia haliotis Haldis & Flavobacteria \\
\hline $\mathrm{A} 3 \mathrm{c}$ & 98 & Ruegeria lacuscaerulensis & $\alpha$-proteobacteria \\
\hline \multicolumn{3}{|r|}{ h 48} & Flavobacteria \\
\hline A1b & 92 & Flavobacteriaceae bacterium & \\
\hline A2a & 90 & Paracoccus versatus & \\
\hline $\mathrm{A} 2 \mathrm{~b}$ & 82 & Vibrio sp. & $\gamma$-proteobacteria \\
\hline A2c & 91 & Uncultured bacterium clone & \\
\hline A2d & 100 & Donglicola eburneus & $\alpha$-proteobacteria \\
\hline $\mathrm{A} 3 \mathrm{~b}$ & 90 & Wandonia haliotis Haldis & Flavobacteria \\
\hline $\mathrm{A} 3 \mathrm{c}$ & 92 & Flavobacteriaceae bacterium & \\
\hline A3d & 98 & Ruegeria lacuscaerulensis & $\alpha$-proteobacteria \\
\hline $\mathrm{A} 3 \mathrm{e}$ & 98 & Uncultured bacterium clone & \\
\hline
\end{tabular}


Continuation

\begin{tabular}{|c|c|c|c|}
\hline OTU & $\operatorname{SIM}(\%)$ & Closest relative & Phylogenetic group \\
\hline \multicolumn{4}{|c|}{ Negative control } \\
\hline \multicolumn{4}{|c|}{ h 0} \\
\hline $\mathrm{C} 2 \mathrm{~b}$ & 97 & Flavobacteriaceae bacterium & \\
\hline $\mathrm{C} 2 \mathrm{c}$ & 99 & $\begin{array}{l}\text { Photobacterium damselae subsp. piscicida } \\
12\end{array}$ & $\gamma$-proteobacteria \\
\hline $\mathrm{C} 1 \mathrm{a}$ & 89 & Flavobacteriaceae bacterium & \\
\hline $\mathrm{C} 1 \mathrm{~b}$ & 85 & Alpha proteobacterium & \\
\hline $\mathrm{C} 2 \mathrm{a}$ & 91 & Wandonia haliotis Haldis & Flavobacteria \\
\hline $\mathrm{C} 2 \mathrm{~b}$ & 97 & Flavobacteriaceae bacterium & \\
\hline $\mathrm{C} 2 \mathrm{c}$ & 89 & Sebaldella termitidis & Fusobacteria \\
\hline $\mathrm{C} 2 \mathrm{f}$ & 96 & Uncultured bacterium clone & \\
\hline $\mathrm{C} 2 \mathrm{~g}$ & 89 & Elizabethkingia anophelis & Flavobacteria \\
\hline $\mathrm{C} 3 \mathrm{a}$ & 99 & Thalassobius sp. & $\alpha$-proteobacteria \\
\hline $\mathrm{C} 3 \mathrm{~b}$ & 93 & Thioprofundum lithotrophica & $\gamma$-proteobacteria \\
\hline $\mathrm{C} 3 \mathrm{c}$ & 97 & Ruegeria lacuscaerulensis & $\alpha$-proteobacteria \\
\hline $\mathrm{C} 3 \mathrm{f}$ & 91 & Uncultured bacterium clone & \\
\hline \multicolumn{4}{|c|}{ h 48} \\
\hline $\mathrm{C} 1 \mathrm{a}$ & 92 & Vibrio mediterranei & $\gamma$-proteobacteria \\
\hline $\mathrm{C} 1 \mathrm{~b}$ & 98 & Ruegeria lacuscaerilensis & $\alpha$-proteobacteria \\
\hline $\mathrm{C} 1 \mathrm{c}$ & 99 & Uncultured bacterium clone & \\
\hline $\mathrm{C} 2 \mathrm{a}$ & 95 & Oceanicola sp. & $\alpha$-proteobacteria \\
\hline $\mathrm{C} 2 \mathrm{~b}$ & 91 & Flavobacteriaceae bacterium & \\
\hline $\mathrm{C} 2 \mathrm{c}$ & 97 & Ruegeria lacuscaerulensis & \\
\hline $\mathrm{C} 2 \mathrm{~d}$ & 92 & Vibrio sp. & $\gamma$-proteobacteria \\
\hline $\mathrm{C} 2 \mathrm{e}$ & 97 & Uncultured bacterium clone & \\
\hline $\mathrm{C} 3 \mathrm{a}$ & 97 & Thalassobius mediterraneus & $\alpha$-proteobacteria \\
\hline $\mathrm{C} 3 \mathrm{~b}$ & 92 & Thioclava pacifica & \\
\hline $\mathrm{C} 3 \mathrm{c}$ & 97 & Ruegeria lacuscaerulensis & $\alpha$-proteobacteria \\
\hline $\mathrm{C} 3 \mathrm{~d}$ & 87 & Uncultured bacterium clone & \\
\hline \multicolumn{4}{|c|}{$\begin{aligned} \text { Positive control } \\
\end{aligned}$} \\
\hline \multicolumn{4}{|c|}{ h 0} \\
\hline $\mathrm{C} 2 \mathrm{c}$ & 99 & Uncultured bacterium clone & \\
\hline $\mathrm{C} 3 \mathrm{~b}$ & 97 & Uncultured bacterium clone & \\
\hline $\mathrm{C} 3 \mathrm{c}$ & \multicolumn{3}{|c|}{ h 12} \\
\hline $\mathrm{C} 1 \mathrm{a}$ & 90 & Wandonia haliotis Haldis & Flavobacteria \\
\hline $\mathrm{C} 1 \mathrm{~b}$ & 97 & Ruegeria lacuscaerulensis & $\alpha$-proteobacteria \\
\hline $\mathrm{C} 1 \mathrm{c}$ & 87 & Uncultured bacterium clone & \\
\hline C1d & 97 & Maribius salinus & $\alpha$-proteobacteria \\
\hline $\mathrm{C} 2 \mathrm{a}$ & 93 & Uncultured bacterium clone & \\
\hline $\mathrm{C} 2 \mathrm{~b}$ & 87 & Uncultured bacterium clone & \\
\hline $\mathrm{C} 2 \mathrm{c}$ & 95 & Thalassobius sp. & $\alpha$-proteobacteria \\
\hline $\mathrm{C} 3 \mathrm{a}$ & 87 & Uncultured bacterium clone & \\
\hline $\mathrm{C} 3 \mathrm{~b}$ & 88 & Uncultured bacterium clone & \\
\hline $\mathrm{C} 3 \mathrm{c}$ & 90 & Donghicola eburneus & $\alpha$-proteobacteria \\
\hline \multicolumn{4}{|l|}{$\mathrm{T} 48$} \\
\hline $\mathrm{C} 2 \mathrm{a}$ & 91 & Uncultured bacterium clone & \\
\hline $\mathrm{C} 2 \mathrm{~b}$ & 100 & Donghicola sp. & $\alpha$-proteobacteria \\
\hline $\mathrm{C} 2 \mathrm{c}$ & 87 & Uncultured bacterium clone & \\
\hline $\mathrm{C} 3 \mathrm{a}$ & 98 & Uncultured bacterium clone & \\
\hline $\mathrm{C} 3 \mathrm{~b}$ & 90 & Wandonia haliotis Haldis & Flavobacteria \\
\hline $\mathrm{C} 3 \mathrm{c}$ & 98 & Ruegeria lacuscaerulensis & $\alpha$-proteobacteria \\
\hline C3d & 98 & Vibrio parahaemolyticus & $\gamma$-proteobacteria \\
\hline $\mathrm{C} 3 \mathrm{e}$ & 92 & Vibrio sp. & $\gamma$-proteobacteria \\
\hline $\mathrm{C} 3 \mathrm{~h}$ & 99 & Uncultured bacterium clone & \\
\hline
\end{tabular}




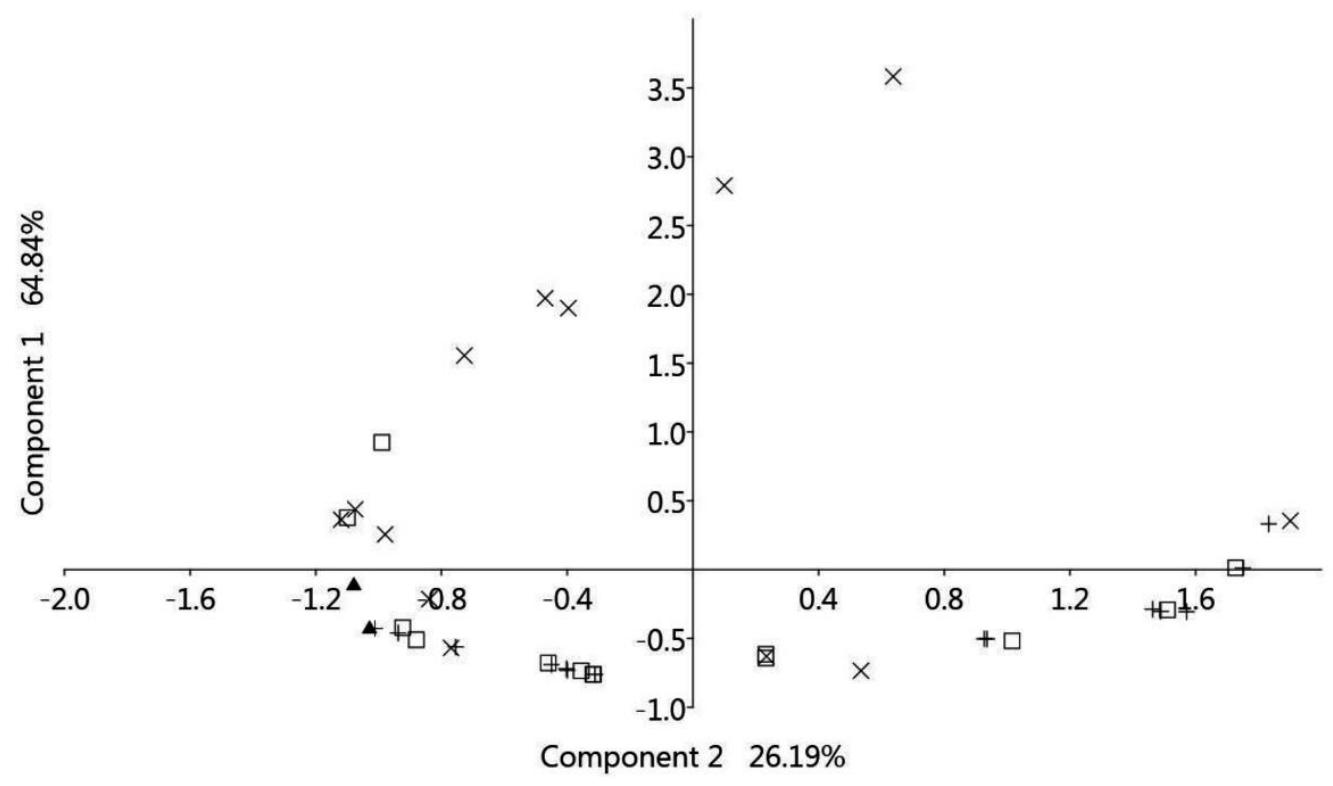

Figure 2. Principal components analysis using the Dice coefficient of single strand conformation SSCP profiles associated with the intestines of individual L. vannamei inoculated with the treatments and challenged with $V$. parahaemolyticus for each time: Time start $(\boldsymbol{\Delta}), 0 \mathrm{~h}(\Delta), 12 \mathrm{~h}(\square), 48 \mathrm{~h}(\times)$. Each point represents a SSCP profile from one shrimp.

Recent studies on the modulation and stabilization of gut microbiota by probiotic treatment suggest that probiotics can exert a positive effect on uncultivable gut microbiota (Sáenz de Rodrigáñez et al., 2009; Sun et al., 2012a, 2012b; Yang et al., 2012), which coincides with the modification of the gut microflora and the increase in bacterial diversity after probiotic administration reported in Solea senegalensis by TapiaPaniagua et al. (2010). Several studies indicated that the culturable intestinal microbial community of shrimp was mainly composed of Aeromonas, Plesiomonas, Photobacterium, Pseudoalteromonas, Pseudomonas and Vibrio species (Moss et al., 2000; Oxley et al., 2002). Of these, only Photobacterium and Pseudoalteromonas were detected in this work whereas Vibrio species were detected only in the positive control (V. parahaemolyticus, confirming the induced infection, and Vibrio sp.), and in shrimps treated with Alibio (Vibrio sp.), possibly because several Vibrio or Vibrio-related species are common in commercial probiotic mixtures (Verschuere et al., 2000; Qi et al., 2009).

In our case, the indigenous intestinal microbiota tended to be dominated by Wandonia haliotis Haldis, which may be considered a commensal, because it was present at all times and in all treatments. The presence of $V$. mediterranei in the negative control may be due to its occurrence in natural microbiota, because this species is commonly associated to a wide-range of hosts, with mutual interactions which may range from mutualism or symbiosis to a pathogenic relation (Turner et al., 2009; Senderovich et al., 2010).

The fact that shrimps treated with the Bacillus mix did not show the presence of the pathogen injected may be taken as an indication of a protective effect of this probiotic, similar to the effect against $V$. parahaemolyticus of the indigenous intestinal microbiota modified with a Bacillus-based probiotic observed by Wu et al. (2014) in the mud crab S. paramamosain. Modifications of the intestinal microflora by a probiotic Bacillus resulting in inhibition of growth of intestinal Vibrio spp. have been reported also in Penaeus monodon by Rengpipat et al. (2000) and by Vaseeharan \& Ramasamy (2003), who also noted a positive effect in the external water environment.

Photobacterium damselae subsp. piscicida was observed in all our treatments. This microorganism (formerly Pasteurella piscicida) is a highly pathogenic bacterium that causes photobacteriosis and does not show host specificity (Toranzo et al., 1991; Noya et al., 1995) but, in spite of its generalized presence it did not show any pathogenic effect, possibly because the presence of the probiotic Bacillus strains, since these are known to modulate shrimp gut bacterial communities (Luis-Villaseñor et al., 2013), thereby improving their immune response against pathogenic bacteria (Zokaeifar et al., 2012, 2014).

The effect of probiotic protection on the structure of the intestinal bacterial community of shrimp infected with pathogenic bacteria was unknown, and this work 
shows that both probiotic mixtures, Alibio and Bacillus mix, helped to maintain a natural balance in the bacterial community of the shrimps intestine, modulating and increasing diversity and evenness of bacterial species in shrimps challenged by bacterial infection.

\section{ACKNOWLEDGMENTS}

Supported by SEP-CONACyT Grant 25981. Hector Acosta of CIBNOR provided technical assistance during the preparation of the manuscript.

\section{REFERENCES}

Abraham, J.T. \& R. Palaniappan. 2004. Distribution of luminous bacteria in semi-intensive penaeid shrimp hatcheries of Tamil Nadu, India. Aquaculture, 232: 8190.

Austin, B. 2006. The bacterial microflora of fish, revised. Sci. World J., 6: 931-945.

Balcázar, J.L., I. de Blas, I. Ruiz-Zarzuela, D. Cunningham, D. Vendrell \& J.L. Múzquiz. 2006. The role of probiotics in aquaculture. Vet. Microbiol., 114: 173-186.

Benbouza, H., J.M. Jacquemin, J.P. Baudoin \& G. Mergeai. 2006. Optimization of a reliable, fast, cheap and sensitive silver staining method to detect SSR markers in polyacrylamide gels. Biotechnol. Agron. Soc. Environ., 10: 77-81.

Chaiyapechara, S., W. Rungrassamee \& I. Suriyachay. 2011. Bacterial community associated with the intestinal tract of $P$. monodon in commercial farms. Microbiol. Ecol., 63: 938-953.

Chatterjee, S. \& S. Haldar. 2012. Vibrio related diseases in aquaculture and development of rapid and accurate identification methods. J. Mar. Sci. Res. Dev., S1:002. doi:10.4172/2155-9910.S1-002.

Chun, J., J.H. Lee, Y. Jung, M. Kim, S. Kim, B.K. Kim \& Y.W. Lim. 2007. EzTaxon: a web-based tool for the identification of prokaryotes based on $16 \mathrm{~S}$ ribosomal RNA gene sequences. Int. J. Syst. Evol. Microbiol., 57: 2259-2261.

Dohrmann, A.B. \& C.C. Tebbe. 2004. Microbial community analysis by PCR-single-strand conformation polymerphism (PCR-SSCP). In: G.A. Kowalchuk, F.J. de Bruijn, I.M. Head, A.J. Van der Zijpp \& J.D. Van Elsas (eds.). Molecular microbial ecology manual. Springer, New York, pp. 809-838.

Fromin, N., J. Hamelin, S. Tarnawski, D. Roesti, K. Jourdain-Miserez, N. Forestier, F. Gillet, M. Aragno \& P. Rossi. 2002. Statistical analysis of denaturing gel electrophoresis (DGE) fingerprinting patterns. Environ. Microbiol., 4: 634-643.
Gopal, S., S.K. Otta, S. Kumar, I. Karunasagar, M. Nishibuchi \& I. Karunasagar. 2005. The occurrence of Vibrio species in tropical shrimp culture environments; implications for food safety. Int. J. Food Microbiol., 102: 151-159.

Hassan, H.A. 2012. 16S rRNA gene-based bacterial community in polychlorinated biphenyls (PCBs) contaminated site using PCR-single-strand conformation polymorphism (SSCP). Life Sci. J., 9: 935-939.

Ishimaru, K., M. Akagawa-Matsushita \& K. Muroga. 1995. Vibrio penaeicida sp. nov., a pathogen of kuruma prawns (Penaeus japonicus). Int. J. Syst. Bacteriol., 45: 134-138.

Jayasree, L., P. Janakiram \& R. Madhavi. 2006. Characterization of Vibrio spp. associated with diseased shrimp from culture ponds of Andhra Pradesh (India). J. World Aquacult. Soc., 37: 523-532.

Lightner, D.V. 2005. Biosecurity in shrimp farming: pathogen exclusion through use of SPF stock and routine surveillance. J. World Aquacult. Soc., 36: 229248.

Luis-Villaseñor, I.E., M.E. Macías-Rodríguez, B. GómezGil, F. Ascencio-Valle \& A.I. Campa-Córdova. 2011. Beneficial effects of four bacillus strains on the larval cultivation of Litopenaeus vannamei. Aquaculture, 321: 136-144.

Luis-Villaseñor, I.E., T. Castellanos-Cervantes, B. Gomez-Gil, A.E. Carrillo-García, A.I. CampaCórdova \& F. Ascencio. 2013. Probiotics in the intestinal tract of juvenile whiteleg shrimp Litopenaeus vannamei: modulation of the bacterial community. World J. Microbiol. Biotechnol., 29: 257265.

Manefield, M., L. Harris, S.A. Rice, R. De Nys \& S. Kjelleberg. 2000. Inhibition of luminescence and virulence in the black tiger prawn (Penaeus monodon) pathogen Vibrio harveyi by intercellular signal antagonists. Appl. Environ. Microbiol., 66: 20792084.

Martínez-Cruz, P., A.L. Ibáñez, O.A. Monroy-Hermosillo \& H.C. Ramírez-Saad. 2012. Use of probiotics in aquaculture. ISRN Microbiol., 2012: Article ID 916845. doi: 10.5402/2012/916845.

Moss, S.M., B.R. LeaMaster \& J.N. Sweeney. 2000. Relative abundance and species composition of gramnegative, aerobic bacteria associated with the gut of juvenile white shrimp Litopenaeus vannamei reared in oligotrophic well water and eutrophic pond water. J. World Aquacult. Soc., 31: 255-263.

Muyzer, G. \& K. Smalla. 1998. Application of denaturing gradient gel electrophoresis (DGGE) and temperature gradient gel electrophoresis (TGGE) in microbial ecology. Antonie Van Leeuwenhoek, 73: 127-141. 
Noya, M., B. Magarinos \& J. Lamas. 1995. Interactions between peritoneal exudate cells (PECs) of gilthead seabream (Sparus aurata) and Pasteurella piscicida. A morphological study. Aquaculture, 131: 11-21.

Oxley, A.P.A., W. Shipton, L. Owens \& D. McKay. 2002. Bacterial flora from the gut of the wild and cultured banana prawn, Penaeus merguiensis. J. Appl. Microbiol., 93: 214-223.

Pérez, T., J.L. Balcázar, I. Ruiz-Zarzuela, N. Halaihel, D. Vendrell, I. de Blas \& J.L. Muzquiz. 2010. Hostmicrobiota interactions within the fish intestinal ecosystem. Mucosal. Immunol., 3: 355-360.

Qi, Z., X.H. Zhang, N. Boon \& P. Bossier. 2009. Probiotics in aquaculture of China-Current state, problems and prospect. Aquaculture, 290: 15-21.

Rengpipat, S., S. Rukpratanporn, S. Piyatiratitivorakul \& P. Menasaveta. 2000. Immunity enhancement in black tiger shrimp (Penaeus monodon) by a probiont bacterium (Bacillus S11). Aquaculture, 191: 271-288.

Sáenz de Rodrigáñez, M.A., P. Díaz-Rosales, M. Chabrillón, H. Smidt, S. Arijo, J.M. León-Rubio, F.J. Alarcón, M.C. Balebona, M.A. Moriñigo, J.B. Cara \& F.J. Moyano. 2009. Effect of dietary administration of probiotics on growth and intestine functionality of juvenile senegalese sole (Solea senegalensis, Kaup 1858). Aquacult. Nutr., 15: 177-185.

Sahul-Hameed, A.S., P.V. Rao, J.J. Farmer, W. HickmanBrenner \& G.R. Fanning. 1996. Characteristics and pathogenicity of a Vibrio cambelli-like bacterium affecting hatchery-reared Penaeus indicus (Milne Edwards, 1837) larvae. Aquacult. Res., 27: 853-863.

Sambrook, J. \& D.W. Russell. 2001. Molecular cloning a laboratory manual. Cold Spring Harbor Laboratory Press, New York, 2231 pp.

Schwieger, F. \& C.C. Tebbe. 1998. A new approach to utilize PCR-single-strand-conformation polymorphism for $16 \mathrm{~S}$ rRNA gene-based microbial community analysis. Appl. Environ. Microbiol., 64: 4870-4876.

Senderovich, Y., I. Izhaki \& M. Halpern. 2010. Fish as reservoirs and vectors of Vibrio cholerae. PLoS ONE, 5(1), e8607. doi:10.1371/journal.pone.0008607.

Sun, Y.Z., H.L. Yang, R.L. Ma \& S.W. Zhai. 2012a. Does dietary administration of Lactococcus lactis modulate the gut microbiota of grouper, Epinephelus coioides. J. World Aquacult. Soc., 43: 198-207.

Sun, Y.Z., H.L. Yang, R.L. Ma, K.P. Huang \& J.D. Ye. 2012b. Culture-independent characterization of the autochthonous gut microbiota of grouper Epinephelus coioides following the administration of probiotic Enterococcus faecium. Aquacult. Int., 20(4), 791-801. doi:10.1007/s10499-012-9503-y.
Tapia-Paniagua, S.T., M. Chabrillón, P. Díaz-Rosales, I.G. de la Banda, C. Lobo, M.C. Balebona \& M.A. Moriñigo. 2010. Intestinal microbiota diversity of the flat fish Solea senegalensis (Kaup, 1858) following probiotic administration. Microbiol. Ecol., 60: 310319.

Toranzo, A.E., S. Barreiro, J.F. Casal, A. Figueras, B. Magariños \& J.L. Barja, 1991. Pasteurellosis in cultured gilthead seabream (Sparus aurata): first report in Spain. Aquaculture, 99: 1-15.

Turner, J.W., B. Good, D. Cole \& E.K. Lipp. 2009. Plankton composition and environmental factors contribute to Vibrio seasonality. ISME J., 3: 10821092.

Tuyub-Tzuc, J.T., D. Rendíz-Escalante, R. Rojas-Herrera, G. Gaxiola-Cortés \& M.L. Arena-Ortíz. 2014. Microbiota from Litopenaeus vannamei: digestive tract microbial community of Pacific white shrimp (Litopenaeus vannamei). SpringerPlus, 3: 280. doi: 10.1186/2193-1801-3-280.

Vaseeharan, B. \& P. Ramasamy. 2003. Control of pathogenic Vibrio spp. by Bacillus subtilis BT23, a possible probiotic treatment for black tiger shrimp Penaeus monodon. Lett. Appl. Microbiol., 36: 83-87.

Verschuere, L., G. Rombaut, P. Sorgeloos \& W. Verstraete. 2000. Probiotic bacteria as biological control agents in aquaculture. Microbiol. Mol. Biol. Rev., 64: 655-671.

Wu, H.J., L.B.Sun, C.B. Li, Z.Z. Li, Z. Zhang, X.B. Wen Z. Hu, Y.L. Zhang, S.K. Li. 2014. Enhancement of the immune response and protection against Vibrio parahaemolyticus by indigenous probiotic Bacillus strains in mud crab (Scylla paramamosain). Fish Shellfish Immunol., 41: 156-162.

Yang, H.L., Y.Z. Sun, R.L. Ma \& J.D. Ye. 2012. PCRDGGE analysis of the autochthonous gut microbiota of grouper Epinephelus coioides following probiotic Bacillus clausii administration. Aquacult. Res., 43: 489-497.

Zokaeifar, H., N. Babaei, C.R. Saad, M.S. Kamarudin, K. Sijam \& J.L. Balcazar. 2014. Administration of Bacillus subtilis strains in the rearing water enhances the water quality, growth performance, immune response, and resistance against Vibrio harveyi infection in juvenile white shrimp, Litopenaeus vannamei. Fish Shellfish Immunol., 36: 68-74.

Zokaeifar, H., J.L. Balcázar, C.R. Saad, M.S. Kamarudin, K. Sijam, A. Arshad \& N. Nejat. 2012. Effects of Bacillus subtilis on the growth performance, digestive enzymes, immune gene expression and disease resistance of white shrimp, Litopenaeus vannamei. Fish Shellfish Immunol., 33: 683-689. 